\title{
PERANCANGAN MODEL OPTIMASI ALOKASI JUMLAH SERVER UNTUK MEMINIMALKAN TOTAL ANTREAN PADA SISTEM ANTREAN DUA ARAH PADA GERBANG TOL
}

\author{
${ }^{1}$ Rio Aurachman, ${ }^{2}$ Ari Yanuar Ridwan \\ ${ }^{12}$ Program Studi Teknik Industri, Fakultas Rekayasa Industri, Universitas Telkom \\ ${ }^{1}$ rioaurachman@telkomuniversity.ac.id ${ }^{2}$ ariyanuar@telkomuniversity.ac.id
}

\begin{abstract}
Abstrak-Terdapat beberapa sistem antrean menggunakan sistem dua arah input dan output pada satu gerbang. Sebagai contoh adalah gerbang tol. Antrean terjadi pada kedua arah; input yaitu masuk ke dalam ruas tol dan output yaitu keluar dari ruas tol menuju jalan umum. Optimasi tidak bisa dilakukan pada satu sisi input saja atau pun pada satu sisi output saja. Perlu didapatkan sebuah metode untuk mengoptimalkan alokasi gardu secara simultan baik input maupun output. Pendekatan yang dilakukan adalah pemodelan matematika dengan memodifikasi dari formulasi antrean yang telah dikembangkan sebelumnya. Pemodelan matematika menggunakan metodologi yang diusulkan oleh Daellenbach yaitu memulai dari pemodelan sistem diakhiri dengan pemodelan matematika berserta verifikasi dan validasinya. Didapatkan model matematika yang dapat mengoptimalkan alokasi gardu menyesuaikan dengan deras arus input dan output secara proporsional. Implikasi dari temuan ini adalah menjelaskan bahwa optimasi dari sistem antrean dua arah dapat dilakukan secara bersamaan dan simultan. Implikasi sosial dari temuan ini adalah pengelolaan sistem antrean dua arah sebagaimana di gardu tol ataupun pelabuhan dapat menggunakan perhitungan yang lebih akurat dan optimal untuk kedua sisi input dan output. Fokus temuan ada pada sistem antrean $\mathbf{M} / \mathbf{M} / \mathrm{C}$ yaitu jumlah kedatangan per satuan waktu memoryless berdistribusi poisson, waktu pelayanan memoryless dengan distribusi binomial, dan jumlah server lebih dari satu. Panjang antrean tidak dibatasi, jumlah populasi tidak dibatasi.
\end{abstract}

Kata Kunci : Antrean, pemodelan, M/M/C

\section{Pendahuluan}

Sistem antrean dan model matematika untuk menghitung antrean dikembangkan menggunakan prinsip arus kedatangan berasal dari satu arah yaitu masuk ke dalam sebuah sistem di mana sistem antrean tersebut menjadi gerbang pembatasnya. Beberapa sistem antrean tidak saja menjadi gerbang pembatas masuknya entitas tapi juga menjadi gerbang pembatas keluarnya entitas.

Beberapa sistem antrean memungkinkan server yang ada berperan sekaligus sebagai input dan output. Ketika server berperan sebagai input, fungsi output tidak berfungsi. Ketika server berperan sebagai fungsi output, fungsi input tidak berfungsi. Dinamisasi tersebut mungkin terjadi khususnya terhadap sistem antrean yang utility-nya bersifat musiman. Adakalanya jumlah kedatangan input besar adapula kalanya kedatangan dari arus output lebih besar. Fleksibilitas tersebut akan menguntungkan bagi sistem diakarenakan dimungkinkan didapatkan kombinasi adaptif menyesuaikan dengan keadaan lingkungan. Konfigurasi input output yang permanen akan menyebabkan paradox pelayanan. Dimungkinkan akan terjadi suatu server input demikian sibuk tetapi server output kosong dan menggangur. Ketimpangan dan paradox tersebut dapat dicegah dengan menggunakan alokasi yang fleksibel.

Model matematika utnuk menghitung panjang antrean sudah berkembang sekian lama. Tetapi sebuah insitatif untuk menyediakan solusi perhitungan dari permasalahan yang telah disebutkan pada paragraf sebelumnya perlu dilakukan. Perlu ada sebuah landasan kebijakan bagi pengambil keputusan dalam menentukan alokasi yang tepat dan mengoptimumkan performa antrean untuk kedua sisi secara simultan tidak secara sendiri-sendiri.

\section{RELATED WORKS}

Beberapa penlitian terlah dilakukan untuk memberikan usulan pengelolaan antrean gerbang tol yang lebih baik. Simulasi telah menjadi salah satu metode untuk melakukan analisis dan peningkatan performansi sistem Hasil simulasi terdahulu menunjukkan bahwa jumlah gerbang tol yang dioperasikan di suatu ruas jalan tol dan lamanya pemrosesan di gerbang tol pun sangat mempengaruhi kelancaran arus kendaraan [1].

Telah dilakukan juga penelitian yang merekomendasikan pembukaan gerbang tol yang disesuaikan dengan laju kedatangan kendaraan sebagaimana diusulkan oleh sediono [2]. Penerapan strategi 'buka-tutup' gerbang tol cukup efektif dalam mengantisipasi perubahan laju kedatangan kendaraan yang dinamis. Lebih dari itu, dinamika strategi 'buka-tutup' dan laju kedatangan kendaraan yang senantiasa berubah dapat terekam dengan baik lewat kurva kerapatan normal lalu-lintas [2]. Dinamisasi itu pun dapat dilakukan dengan menyesuaikan kepadayan kendaraan di jalan tol. dapat dilakukan dinamisasi jumlah gardu tol disesuaikan dengan sif kepadatan kedatangan entitas [3] Selain itu faktor biaya dapat menjadi pertimbangan dalam penentuan jumlah gardu tol yang dibuka tersebut. Dapat dilakukan optimasi biaya gardu yang beroperasi dengan cara menyesuaikan jumlah gardu beroperasi dengan arus kedatangan kendaraan [3] perilaku dan karakteristik lalu lintas 
mengalami perubahan dari waktu ke waktu. Dimungkinkan untuk didapatkan nilai ekivalensi mobil penumpang pada ruas jalan tol, dimana contoh dari kajian dilakukan pada ruas jalan tol Jakarta - Cikampek [4].

Simulasi dan analisis dapat ditunjang dengan menggunakan software sebagaimana diusulkan Sediono [2]. Pemodelan kondisi antrean di gerbang tol telah berhasil diimplementasikan ke dalam software yang sederhana. Atas dasar prinsip yang mudah dipahami, dengan membuat struktur data dan alur diagram yang sesuai, software ini cukup fleksibel. Dari diskusi di atas dapat disimpulkan bahwa panjang antrean yang diinginkandapat diatur dengan melakukan kontrol terhadap arus kendaraan masuk dan keluar [2].

Penggunaan perangkat keras sebagai deteksi otomatis dari kedatangan kendaraan untuk lalu diolah menjadi data dan informais yang bermanfaat bagi pengambil keputusan. Alat ini menggunakan sensor pendeteksi logam untuk mendeteksi antrean kendaraan, sensor ditanam di ruas jalan tol dan bekerja dengan cara mendeteksi logam yang ada pada kolong kendaraan. Informasi kepadatan maupun kemacetan tersebut juga dapat diakses dengan menggunakan layanan pesan singkat melalui ponsel. Sistem yang diterapkan pada alat ini dapat membuat proses dalam memantau dan menginformasikan kemacetan yang terjadi pada ruas jalan tol menjadi update terus menerus secara otomatis [5].

Muara dari pengaturan gardu tol adalah pada peningkatan kepuasan pelanggan. Terdapat penelitian terdahulu yang mengusulkan sebuah metode evluasi kepuasan pelanggan menggunakan beberapa atribut penilaian. Atribut yang diteliti mengacu pada lima dimensi utama kualitas layanan jasa, yaitu Tangibles, Reliability, Responsiveness, Assurance dan Emphaty. Data survei yang diperoleh selanjutnya dianalisis dengan menggunakan metode Importance Performance Analysis (IPA) Berdasarkan analisis Importance Performance Analysis (IPA), beberapa atribut layanan

yang perlu mendapatkan perhatian penanganan guna peningkatan kinerjanya adalah:

a. kelancaran arus lalu lintas;

b. antrean pembayaran di pintu tol tidak panjang dan cepat.

c. kondisi jalan tol yang bersih dan rapi;

d. kondisi tikungan, tanjakan, dan turunan jalan yang aman dan nyaman saat dilintasi;

e. kondisi permukaan jalan tol yang rata dan tidak licin;

f. kondisi lampu penerangan jalan membuat nyaman pengendara di malam hari;

g. tersedianya pagar pengaman median dan pagar pembatas jalan tol. [6]

Teknologi lain yang dapat digunakan untuk meningkatkan performa jalan tol adalah menggunakan konsep E-Toll.

Widyani [7] meneliti pengaruh dari impelementasi E-Toll. Berikut adalah salah satu hasil dari penelitian tersebut. Perceived usefulness mempengaruhi secara positif terhadap attitude pengguna jalan tol Kota Bandung apabila E-Toll diimplementasikan dan perceived behavioral control, perceived usefulness, subjective norm \& attitude mempengaruhi secara positif terhadap niat penggunaan E-Toll Card.

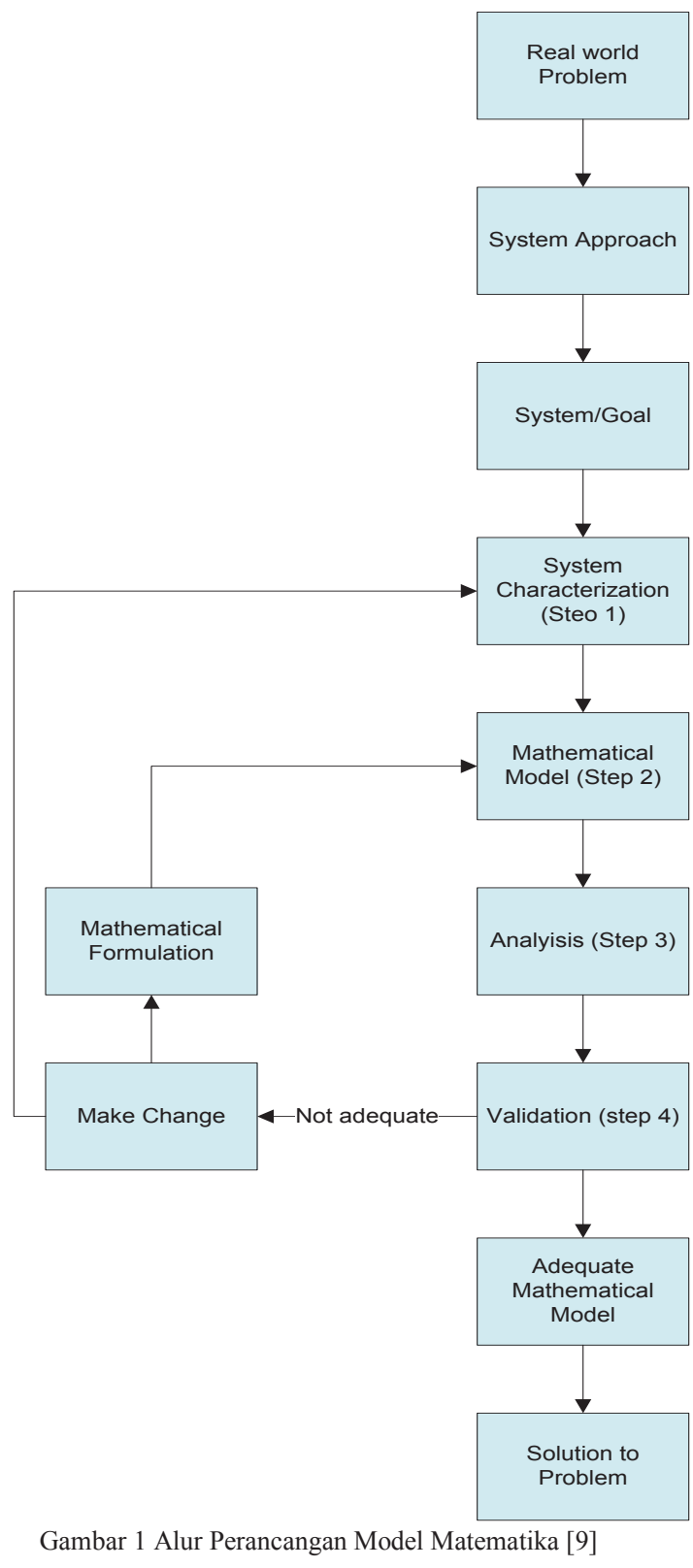

kesiapan pengguna jalan tol Kota Bandung apabila E-Toll Card diimplementasikan di pintu tol Kota Bandung dengan menggunakan model integrasi Technology Acceptance Model (TAM) \& Theory Planned Behavior (TPB)[7]

Kajian terhadap antrean selain pada 26 ariab jalan tol, juga dilakukan pada 26ariab antrean lainnya. Salah satunya adalah penelitian yang dilakukan oleh Kurniawan [8].untuk 26ariab pintu keluar Solo Grand Mall. Pengaruh antrean kendaraan dan volume kendaraan yang melintasi pelayanan pintu keluar Solo Grand Mal ditinjau dari segi tingkat kedatangan kendaraan dan tingkat pelayanan. Penyelesaian kasus ini menggunakan teori antrean dengan disiplin antrean First In First Out (FIFO). Perhitungan analisis 26ariable26 pada tingkat kedatangan berdasarkan distribusi poisson dengan uji Chi Square dan analisis 26ariable26 tingkat pelayanan berdasarkan distribusi eksponensial dengan uji Kolmogorov-Smirnov. 


\section{METODOLOGI}

Sebagiamana digambarkan pada Gambar 1 [9], proses dari pengembangan model matematika diawali dengan meninjau sebuah permasalahan nyata yang terjadi di sebuah 27 ariab. Lalu melakukan pendekatan 27ariab kepada permasalahan tersebut sehingga didapatkan sebuah sudut pandang holistic dan helicopter view. Sudut pandang 27ariab ini menyebabkan solusi yang dihasilkan dapat menjadi optimal secara global dan bukan optimal secara 27aria saja. Dalam 27ariab antrean jalan tol, pendekatan 27 ariab tercitra dalam bentuk meninjau tidak saja antrean gardu masuk tetapi juga gardu keluar sekaligus. Pendekatan 27ariab ini mempertimbangkan system relevan yang ditinjau adalah satu buah gardu di ujung jalan tol tetapi tidak meninjau 27ariab secara keseluruhan.

Setelah melakukan pendekatan 27ariab, maka ditentukanlah tujuan atau permasalahan yang akan diselesaikan dan karakterisasi 27ariab. Beberapa diagram dapat digunakan untuk menggambarkan hal tersebut salah satunya adalah influence diagram [10].

Tahap berikutnya adalah merancang model matematika berdasarkan dari influence diagram yang telah dirancang. Setelah model matematika dirancang tahap berikutnya adalah melakukan analisis dan validasi serta verifikasi. Metode validasi yang digunakan adalah melakukan pengecekan setiap hubungan yang terdapat dalam influence diagram terekspresi pada model matematika. Verifikasi dapat dilakukan dengan cara memastikan satuan dari persamaan, baik ruas kiri dan ruas kanan, adalah sama.

Pada tahap validasi dapat tercetus sebuah kesimpulan apakah model perlu diperbaiki atau tidak hingga model tersebut valid dan terverifikasi. Setelah proses 27 ariable27 terjadi maka tahap terakhir adalah terbentuknya model matematika yang tepat sehingga bisa digunakan dalam penyelesaian permasalahan.

\section{IV.PENGEMBANGAN MODEL}

\subsection{Model Konseptual}

Model konseptual pada penelitian ini ditunjukkan pada influence diagram sistem antrean gardu tol (Gambar 2).

\subsection{Model Matematika}

Berikut adalah proses pengembangan model matematika yang dilakukan berdasarkan model konseptual dengan format influence diagram yang telah digambarkan pada Gambar 2. Setiap 27ariab panah dari influence diagram menunjukkan keterkaitan antara 27ariable dan atau parameter. Keterkaitan tersebut diekspresikan dalam bentuk persamaan matematika.

a. Target Model

Target dari model adalah optimasi $\mathrm{Z}$ yakni,

TABEL I

FUNGSI TUJUAN

\begin{tabular}{|c|c|c|}
\hline Penjelasan & Lambang & Satuan \\
\hline Total Rata-rata Jumlah Antrean & $\mathrm{Z}$ & Unit \\
\hline
\end{tabular}

\section{b. Variabel Keputusan}

Variabel keputusan dari model ini adalah jumlah gardu masuk dan jumlah gardu keluar.

TABEL II

VARIABEL KEPUTUSAN

\begin{tabular}{|c|c|}
\hline Lambang & Penjelasan \\
\hline $\mathrm{c}_{1}$ & Jumlah Gardu Masuk \\
\hline $\mathrm{c}_{2}$ & Jumlah Gardu Keluar \\
\hline
\end{tabular}

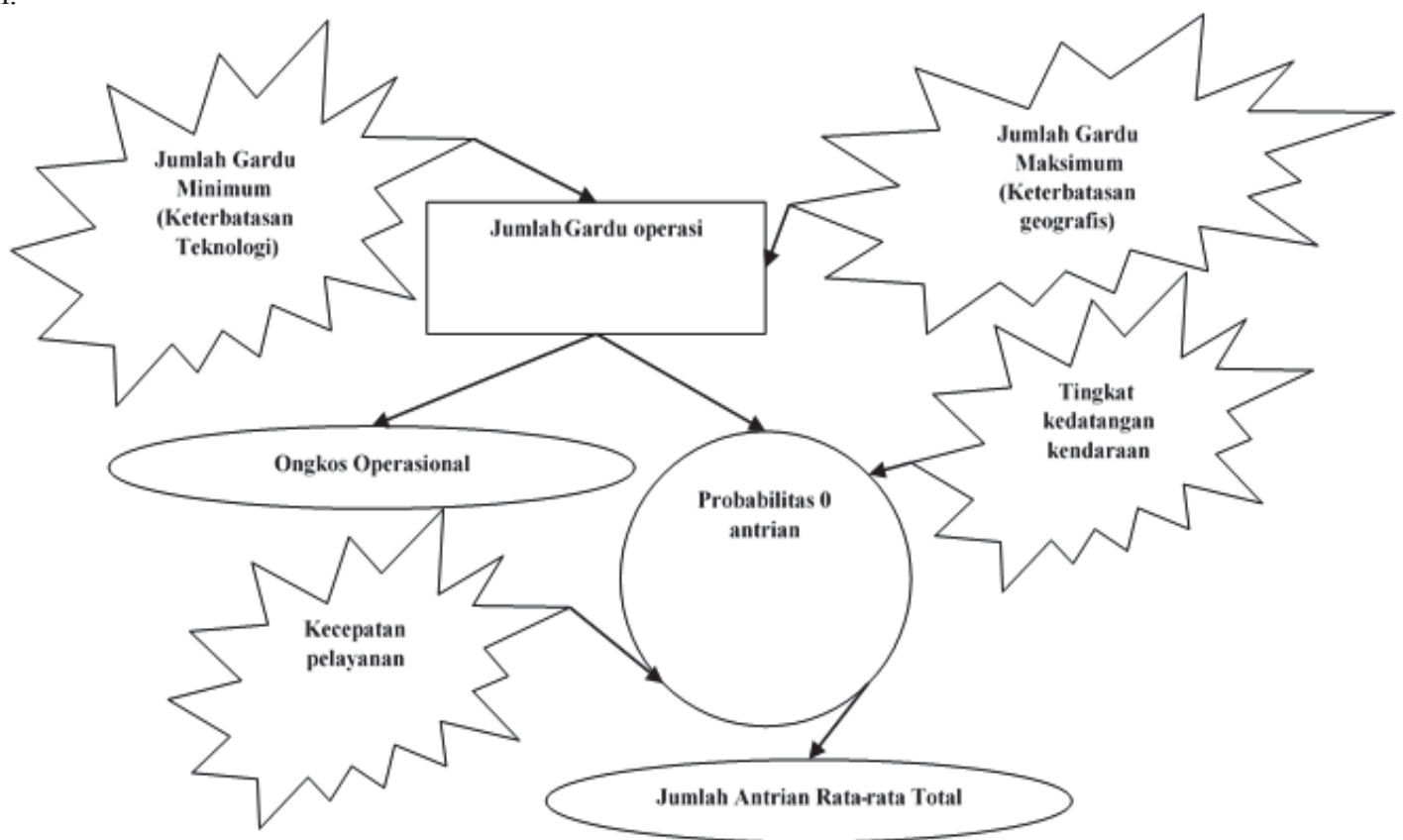

Gambar 2 Influence Diagram Sistem Antrean Gardu Tol 
c. Constraint

Berikut adalah constraint yang terlibat dalam model.

\begin{tabular}{|c|c|c|c|}
\multicolumn{4}{c}{ TABEL III } \\
CONSTRAINT \\
\hline Penjelasan & Lambang & Nilai & Satuan \\
\hline $\begin{array}{c}\text { Jumlah gardu } \\
\text { maksimal di } \\
\text { gerbang tol }\end{array}$ & $\mathrm{C}_{\max }$ & 13 & Gardu \\
\hline
\end{tabular}

\section{d.Parameter}

Pada Tabel IV ditunjukkan parameter-parameter yang terlibat dalam model.

\section{e. Model Matematika}

Untuk menggambarkan total waktu tunggu yang harus ditanggung oleh sistem, yaitu dengan menjumlahkan waktu tunggu untuk gardu masuk dan gardu keluar.

Minimasi $Z=E N_{q 1}+E N_{q 2}$

Subject to:

Untuk menjelaskan kondisi sistem bahwa jumlah gardu dibatasi oleh keterbatasan luas wilayah yang ada.

$$
c_{1}+c_{2} \leq \operatorname{cmax}
$$

Untuk menjelaskan kondisi sistem bahwa jumlah gardu minimal dibatasi oleh jumlah kendaraan maksimum yang mengantre.

TABEL IV

PARAMETER

\begin{tabular}{|c|c|c|c|}
\hline Penjelasan & Lambang & Nilai & Satuan \\
\hline $\begin{array}{l}\text { Laju kedatangan } \\
\text { kendaraan entrance }\end{array}$ & $\mu 1$ & $\begin{array}{l}\text { Menyesuaikan } \\
\text { dengan keadaan } \\
\text { aktual }\end{array}$ & /second \\
\hline $\begin{array}{l}\text { Laju kedatangan } \\
\text { kendaraan exit }\end{array}$ & $\mu 2$ & $\begin{array}{l}\text { Menyesuaikan } \\
\text { dengan keadaan } \\
\text { aktual }\end{array}$ & /second \\
\hline $\begin{array}{l}\text { Laju pelayanan } \\
\text { gardu entrance }\end{array}$ & $\lambda 1$ & $\begin{array}{l}\text { Menyesuaikan } \\
\text { dengan keadaan } \\
\text { aktual }\end{array}$ & /second \\
\hline $\begin{array}{l}\text { Laju pelayanan } \\
\text { gardu exit }\end{array}$ & $\lambda 2$ & $\begin{array}{l}\text { Menyesuaikan } \\
\text { dengan keadaan } \\
\text { aktual }\end{array}$ & /second \\
\hline Faktor Utilisasi & $\rho 1$ & $\frac{\lambda}{c \mu}$ & \\
\hline $\begin{array}{l}\text { Probabilitas } \\
\text { kendaraan entrance } \\
\text { ada di sistem }\end{array}$ & P1n & Hasil Perhitungan & \\
\hline $\begin{array}{l}\text { Probabilitas } \\
\text { kendaraan exit ada } \\
\text { di sistem }\end{array}$ & $\mathrm{P} 2 \mathrm{n}$ & Hasil Perhitungan & \\
\hline $\begin{array}{lr}\text { Laju } & \text { kedatangan } \\
\text { rata-rata efektif } \\
\text { kendaraan entrance }\end{array}$ & $\lambda 1 \mathrm{eff}$ & $\sum_{n=0}^{\sim} \lambda 1 \mathrm{P} 1 \mathrm{n}$ & /second \\
\hline $\begin{array}{l}\text { Laju kedatangan } \\
\text { rata-rata efektif } \\
\text { kendaraan exit }\end{array}$ & $\lambda 2 \mathrm{eff}$ & $\sum_{n=0}^{\sim} \quad \lambda 2 \mathrm{P} 2 \mathrm{n}$ & /second \\
\hline $\begin{array}{l}\text { Biaya untuk gardu } \\
\text { entrance }\end{array}$ & R1 & Akumulasi & Rupiah/jam \\
\hline $\begin{array}{l}\text { Biaya untuk gardu } \\
\text { exit }\end{array}$ & R2 & akumulasi & Rupiah/jam \\
\hline
\end{tabular}

Hubungan yang terjadi antara jumlah kendaraan mengantre dan jumlah gardu adalah bahwa semakin sedikit jumlah gardu, jumlah kendaraan mengantre akan semakin banyak.

$$
\frac{\lambda_{1}^{\mathrm{c}_{1}}}{\mathrm{c}_{1} ! \mu_{1}^{\mathrm{c}_{1}}} \frac{1}{\sum_{\mathrm{n}=0}^{\mathrm{c}_{1}-1} \frac{\lambda_{1}{ }^{\mathrm{n}}}{\mathrm{n} ! \mu_{1}^{\mathrm{n}}}+\frac{1}{\mathrm{c}_{1} !}\left[\frac{\lambda_{1}}{\mu_{1}}\right]^{\mathrm{c}_{1}}\left[\frac{1}{1-\frac{\lambda_{1}}{\mathrm{c}_{1} \mu_{1}}}\right]} \frac{\lambda_{1}}{\mathrm{c}_{1} \mu_{1}} \frac{1}{\left[1-\frac{\lambda_{1}}{\mathrm{c}_{1} \mu_{1}}\right]^{2}}=\mathrm{EN}_{\mathrm{q} 1}
$$

$$
\frac{\lambda_{2}^{\mathrm{c}_{2}}}{\mathrm{c}_{2} ! \mu_{2}^{\mathrm{c}_{2}}} \frac{1}{\sum_{\mathrm{n}=0}^{\mathrm{c}_{2}-1} \frac{\lambda_{2}{ }^{\mathrm{n}}}{\mathrm{n} ! \mu_{2}^{\mathrm{n}}}+\frac{1}{\mathrm{c}_{2} !}\left[\frac{\lambda_{2}}{\mu_{2}}\right]^{\mathrm{c}_{2}}\left[\frac{1}{1-\frac{\lambda_{2}}{\mathrm{c}_{2} \mu_{2}}}\right]} \frac{\lambda_{2}}{\mathrm{c}_{2} \mu_{2}} \frac{1}{\left[1-\frac{\lambda_{2}}{\mathrm{c}_{2} \mu_{2}}\right]^{2}}=E N_{q 2}
$$

Persamaan berikut untuk menjelaskan bahwa jumah gardu yang beroperasi tidak bisa kurang dari satu gardu. Hal tersebut diakibatkan oleh beberapa sebab tuntutan kebutuhan dari masyarakat untuk menggunakan jalan tol, kebutuhan perusahan untuk mendapatkan kompensasi dari pengguna jalan tol untuk digunakan sebagai biaya operasional sistem jalan tol, dan belum didapatkannya teknologi yang dapat menghitung kendaraan dan mengumpulkan dana tanpa harus menggunakan gardu dan mengantre.

$$
\begin{aligned}
& c_{1} \geq 1 \\
& c_{2} \geq 1 \\
& c_{1}, c 2 \text { integer }
\end{aligned}
$$

Verifikasi Model

Berikut akan dilakukan verifikasi terhadap model dengan cara menguji kebenaran dimensi perhitungan matematika yang dilakukan.

\begin{tabular}{|c|c|c|c|}
\hline \multicolumn{4}{|c|}{ VERIFIKASI FUNGSI TUJUAN } \\
\hline $\mathrm{Z}$ & \multirow{2}{*}{$=$} & $\mathrm{EN}_{\mathrm{q} 1}$ & $\mathrm{EN}_{\mathrm{q} 2}$ \\
\hline Unit & & Unit & Unit \\
\hline
\end{tabular}

Verifikasi pertama dilakukan pada fungsi tujuan

$$
\mathrm{Z}=E N_{q 1}+E N_{q 2}
$$

Dari persamaan tersebut.dapat diketahui bahwa satuan untuk tiap variabel dan parameter menjadi

TABEL V

Persamaan pertama lulus verfikasi.

Persamaan kedua yang akan dilakukan verifikasi terhadapnya adalah:

$$
\mathrm{c}_{1}+\mathrm{c}_{2} \leq \mathrm{cmax}
$$

Dari persamaan tersebut.dapat diketahui bahwa satuan untuk tiap variabel dan parameter menjadi

TABEL VI VERIFIKASI CONSTRAINT

\begin{tabular}{|l|c|l|l|}
\hline $\mathrm{c} 1$ & $\mathrm{c} 2$ & & $\mathrm{cmax}$ \\
\cline { 1 - 1 } Gardu & Gardu & $=$ & Gardu \\
\hline
\end{tabular}


Persamaan kedua lulus verifikasi.

Persamaan berikutnya yang akan diuji verifikasi sebagaimana beriku. Meggunakan analisis dimensi, penulisan dimensi untuk persamaan di atas menjadi

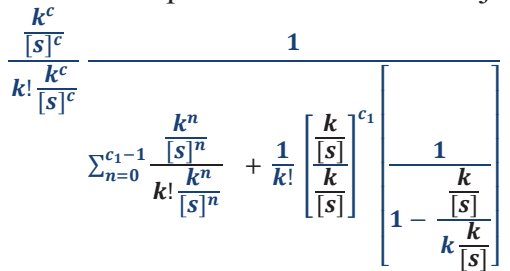

Huruf "k"di menyatakan gardu

Persamaan hasil analisis dimensi di atas dapat disederhanakan menjadi

$$
k \frac{1}{\sum_{n=0}^{c_{1}-1} \mathrm{k}+\frac{1}{k !} k^{c_{1}}\left[\frac{1}{1-k}\right]} \quad k \frac{1}{[1-k]^{2}} \leq k
$$

Semua dimensi saling menedikan sehingga terbukti bahwa

$$
K \approx K
$$

Untuk persamaan selanjutnya pun terjadi proses uji verfifikasi yang relatif sama dibandingkan persamaan sebelumnya.

\section{Validasi}

Berikut akan dilakukan validasi terhadap model dengan cara menguji apakah setiap hubungan di sistem nyata dihubungkan oleh hubungan di model. Penjelasan ini akan mudah dipahami dengan cara mengulang penjelasan influence diagram (Gambar 3).

Setiap notasi panah berhuruf tersebut harus dinyatakan dalam suatu hubungan dalam persamaan yang tertuang pada model matematika.

Notasi A menunjukkan bahwa constraint jumlah gardu maksimum membatasi variabel jumlah gardu operasi. Pernyataan tersebut dinyatakan pada formula $c_{1}+c_{2} \leq c_{\max }$

Dapat dilihat bahwa $\mathrm{C}_{1}$ yang mewakili jumlah gardu entrance dan $\mathrm{C}_{2}$ yang mewakili jumlah gardu exit, akumulasi keduanya dibatasi oleh $\mathrm{C}_{\max }$ yang merupakan kemampuan maksimal gardu dalam memiliki tempat. Kondisi tersebut terjadi dikarenakan luas area yang memang terbatas.

Notasi B menunjukkan bahwa variabel jumlah gardu operasi mempengaruhi probabilitas terdapat 0 antrean. Hubungan tersebut dibatasi oleh formula berikut.

$$
\frac{\lambda_{1}^{c_{1}}}{c_{1} ! \mu_{1}^{c}} \frac{1}{\sum_{n=0}^{c_{1}-1} \frac{\lambda_{1}{ }^{n}}{n ! \mu_{1}^{n}}+\frac{1}{c_{1} !}\left[\frac{\lambda_{1}}{\mu_{1}}\right]^{c_{1}}\left[\frac{1}{1-\frac{\lambda_{1}}{c_{1} \mu_{1}}}\right]} \frac{\lambda_{1}}{c_{1} \mu_{1}} \frac{1}{\left[1-\frac{\lambda_{1}}{c_{1} \mu_{1}}\right]^{2}}=E N_{q 1}
$$

Atau dalam bentuk lain sebagai berikut.

$$
\frac{\lambda_{1}^{c_{1}}}{c_{1} ! \mu_{1}^{c}} P_{0} \frac{\lambda_{1}}{c_{1} \mu_{1}} \frac{1}{\left[1-\frac{\lambda_{1}}{c_{1} \mu_{1}}\right]^{2}}=\mathrm{EN}_{\mathrm{q} 1}
$$

Khususnya bagian:

$$
\frac{1}{\sum_{n=0}^{c_{1}-1} \frac{\lambda_{1}{ }^{n}}{n ! \mu_{1}^{n}}+\frac{1}{c_{1} !}\left[\frac{\lambda_{1}}{\mu_{1}}\right]^{c_{1}}\left[\frac{1}{1-\frac{\lambda_{1}}{c_{1} \mu_{1}}}\right]}=P_{0}
$$

Pada persamaan tersebut dapat dilihat bahwa variabel $c_{1}$ mempuyai hubungan dengan $P_{0}$. Hubungan tersebut dalam bentuk perkalian dan penjumlahan serta pangkat atau batas maksimum berapa kali penjumlahan.

Hal tersebut pun terjadi untuk variabel $\mathrm{C}_{2}$. Notasi $\mathrm{C}$ yaitu hubungan tingkat kedatangan kendaraan dan probabilitas antrean 0 diwakili oleh persamaan.

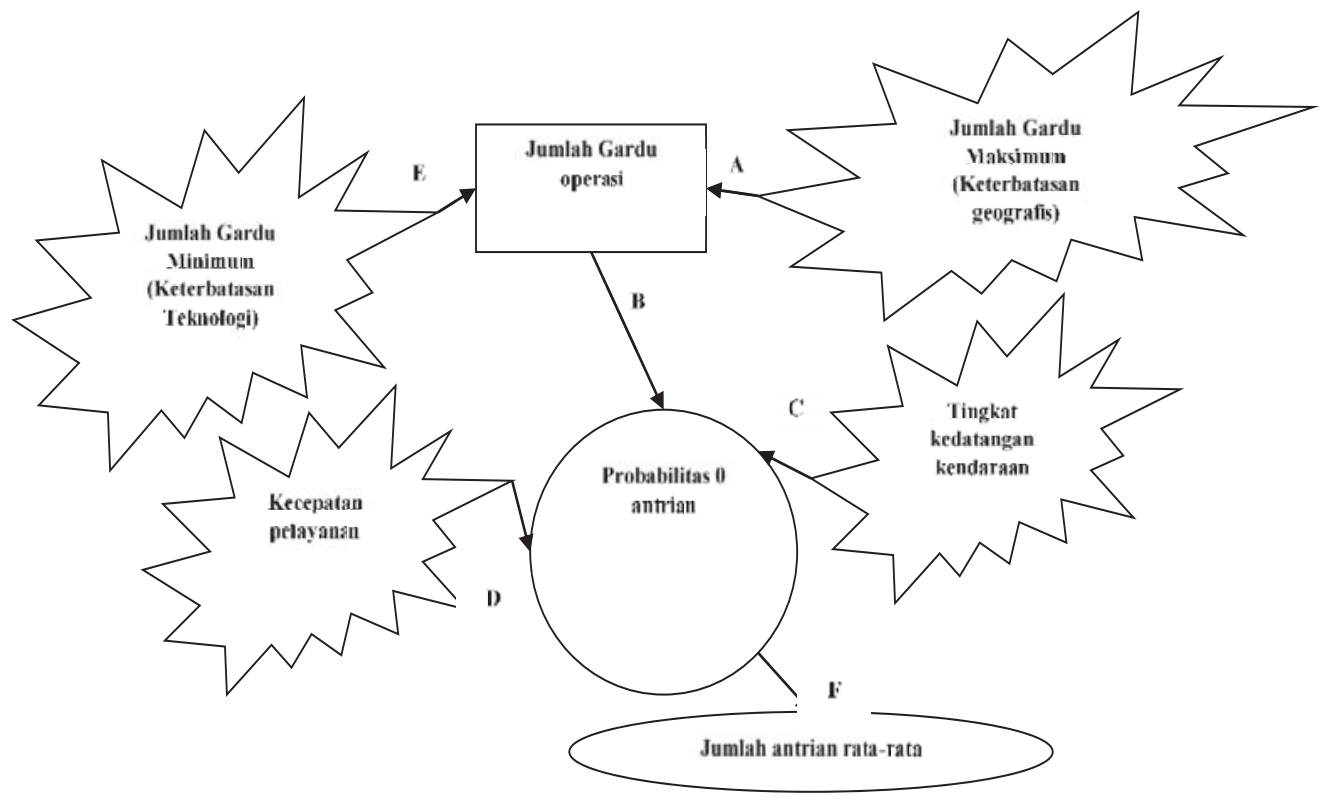

Gambar 3 Validasi Influence Diagram 


$$
\frac{1}{\sum_{n=0}^{c_{1}-1} \frac{\lambda_{1}{ }^{n}}{n ! \mu_{1}^{n}}+\frac{1}{c_{1} !}\left[\frac{\lambda_{1}}{\mu_{1}}\right]^{c_{1}}\left[\frac{1}{1-\frac{\lambda_{1}}{c_{1} \mu_{1}}}\right]}=P_{0}
$$

Variabel-variabel yang berhubungan diwakilkan oleh arsiran berwarna abu-abu. Hubungan tersebut berupa perkalian atau hubungan berbanding terbalik antara $\mathrm{P}_{0}$ dan $\lambda_{1}$.

Notasi D, hubungan antara constraint kecepatan pelayanan dan probabilits 0 pelanggan di dalam antrean terwakili dalam persamaan berikut:

$$
\frac{1}{\sum_{n=0}^{c_{1}-1} \frac{\lambda_{1}{ }^{n}}{n ! \mu_{1}^{n}}+\frac{1}{c_{1} !}\left[\frac{\lambda_{1}}{\mu_{1}^{n}}\right]^{c_{1}}\left[\frac{1}{1-\frac{\lambda_{1}}{c_{1} \mu_{1}^{n}}}\right]}=P_{0}
$$

Hubungan tersebut dapat dilihat antara variabel yang diberi arsir abu-abu. Hubungan tersebut umumnya berupa pembagian atau perbandingan lurus.

Notasi F, hubungan antara probabilitas antrean dalam keadaan nol dan jumlah antrean rata-rata terwakili dalam persamaan berikut:

$$
\frac{\lambda_{1}^{c_{1}}}{c_{1} ! \mu_{1}^{c}} \frac{1}{\sum_{n=0}^{c_{1}-1} \frac{\lambda_{1}{ }^{n}}{n ! \mu_{1}^{n}}+\frac{1}{c_{1} !}\left[\frac{\lambda_{1}}{\mu_{1}}\right]^{c_{1}}\left[\frac{1}{1-\frac{\lambda_{1}}{c_{1} \mu_{1}}}\right]} \frac{\lambda_{1}}{c_{1} \mu_{1}} \frac{1}{\left[1-\frac{\lambda_{1}}{c_{1} \mu_{1}}\right]^{2}}=E N_{q 1}
$$

Atau dalam bentuk lain

$$
\frac{\lambda_{1}^{c}}{c_{1} ! \mu_{1}^{c}} P_{0} \frac{\lambda_{1}}{c_{1} \mu_{1}} \frac{1}{\left[1-\frac{\lambda_{1}}{c_{1} \mu_{1}}\right]^{2}}=E N_{q 1}
$$

karena

$$
\frac{1}{\sum_{n=0}^{c_{1}-1} \frac{\lambda_{1}{ }^{n}}{n ! \mu_{1}^{n}}+\frac{1}{c_{1} !}\left[\frac{\lambda_{1}}{\mu_{1}}\right]^{c_{1}}\left[\frac{1}{1-\frac{\lambda_{1}}{c_{1} \mu_{1}}}\right]}=P_{0}
$$

Sehingga hubungan tersebut dapat dilihat pada

$$
\frac{\lambda_{1}^{c}}{c_{1} ! \mu_{1}^{c}} P_{0} \frac{\lambda_{1}}{c_{1} \mu_{1}} \frac{1}{\left[1-\frac{\lambda_{1}}{c_{1} \mu_{1}}\right]^{2}}=E N_{q}
$$

Hubungan tersebut dapat dilihat antara variabel yang diberi arsir abu-abu. Hubungan tersebut umumnya berupa pembagian atau perbandingan lurus. Setiap kali probabilitas 0 kendaraan meningkat, jumlah antrean pun meningkat.।

Proses validasi menunjukkan bahwa model valid.

Notasi E, hubungan antara batasan gardu minimum dan jumlah gardu terdapat dalam persamaan berikut:

$c_{1} \geq 1$

$c_{2} \geq 1$

Proses validasi menunjukkan bahwa model valid.

\section{KESIMPULAN}

Telah dirancang sebuah model matematika menggunakan pendekatan sistem. Model tersebut dapat menjadi solusi bagi penjadwalan dan alokasi dari penggunaan gardu di setiap ujung jalan tol. Model tersebut dapat melakukan minimasi dari waktu antrean yang ada. Minimasi tersebut diharapkan dapat meningkatkan kepuasan dari konsumen. Model tersebut pun diharapkan dapat mendukung pengambilan keputusan untuk meningkan utitilas dari penggunaan gerbang tol. Peningkatan utilitas tersebut diharapkan untuk meningkatkan efisiensi dari sistem. Perlu pengembangan penelitian selanjutnya yaitu melakukan uji coba model menggunakan data real sehingga dapat dibuktikan peningkatan performa dari sistem setelah menggunakan model matematika ini sebagai penunjang dari pengambilan keputusan. Pengemabngan lainnya yang dapat dilakukan adalah dengan cara memasukkan faktor biaya sebagai pertimbangan dari pengembangan model matematika.

\section{DAFTAR PUSTAKA}

[1] Sediono, Wahju, And Dwi Handoko. "Pemodelan dan Simulasi Antrean Kendaraan Di Gerbang Tol." Proc. Semiloka Bppt 2004 (2004): 11-14.

[2] Sediono, Wahju, And Dwi Handoko. "Pendekatan Simulasi Dalam Mengoptimalkan Pengoperasian Gerbang Tol." Prosiding Semiloka Teknologi Simulasi Dan Komputasi Serta Aplikasinya (2005): 91-94.

[3] Satya, Dwi, And R. Ririn. "Penentuan Loket Yang Optimal Pada Gerbang Selatan Tol Pondok Gede Barat Dengan Menggunakan Teori Antrean Untuk Meminimasi Biaya." Jurnal Teknik Industri 1.3 (2011): 224-230.

[4] Prima, Gary Raya, And Tri Rasuki Joewono3 Hikmat Iskandar. "Kajian Nilai Ekivalensi Mobil Penumpang Berdasarkan Data Waktu Antara Pada Ruas Jalan Tol (Astudyofpassenggercar Egu 1 Valencybasedon Headwayfor Tollroads)." Jurnal Jalan-Jembatan, Volume 31 No. 2 (2014) : 74 - 82

[5] Sugandhi, Sebastianus Adrian. "Perancangan Model Alat Pemantau Dan Petunjuk Informasi Kemacetan Pada Ruas Jalan Tol Dalam Kota Jakarta." Skripsi S-1 Teknik Elektro (2010).

[6] Pancawati, Elis, And Aa Gde Kartika. "Analisis Layanan Jalan Tol Berdasarkan Kebutuhan Pengguna (Studi Kasus Ruas Jalan Tol Surabaya-Gresik)." Prosiding Seminar Nasional Manajemen Teknologi XIX (2013)

[7] Widyani, Dini. "Analisis Adopsi Aplikasi Rfid Pada Produk E-Toll Di Jalan Tol Kota Bandung." Open Library Telkom University (2015)

[8] Kurniawan, Hendra Wahyu, Agus Sumarsono, dan Amirotul Musthofiah Mahmudah. "Evaluasi Panjang Antrean Kendaraan Pada Pelayanan Pintu Keluar Parkir Dengan Atau Tanpa Perubahan Pintu Keluar Parkir Di Solo Grand Mall." Matriks Teknik Sipil 3.1 (2015).

[9] Daellenbach, Hans G,dan Donald C. McNickle(2005). Management Scence. Decision through systems Thinking. University Of Canterbury, Chrstchurch, New Zeland.

[10] Murthy, D.N.P et all,(1990) Mathematical Modelling. Oxford : Pergamon Press. 